\title{
Pembentukan Karakter Islami melalui Pengembangan Mata Pelajaran Akidah Akhlak di Madrasah Aliyah An-Najah Bekasi
}

\author{
${ }^{1}$ Danang Dwi Basuki, ${ }^{2}$ Hari Febriansyah \\ ${ }^{1,2}$ Universitas Islam Negeri (UIN) Sunan Gunung Djati \\ ${ }^{1}$ danangdwibasuki@gmail.com²harisulasman@gmail.com
}

\begin{abstract}
The purpose of this study is to analyze the formation of Islamic character through the development of moral subjects. This research uses descriptive analytic method with data collection instruments through observation, documentation and interviews. The results showed that the Islamic character is a character that originates from Islamic teachings or Islamic character. The formation of Islamic characters in Madrasah Aliyah An-Najah Bekasi through the development of moral subjects has several ways, including: the madrasa head instructs the teacher who teaches moral subjects to pay close attention to the character education that has been launched by the government so that it can be implemented into learning according with the madrasa conditions and pay attention to madrasa vision and mission relating to the application of Islamic character values, teachers of moral subjects are given the freedom to develop existing characters, in accordance with the level of each class and establish communication between homeroom teacher and teacher guidance counseling to see the extent to which the implementation of the Islamic character in students and the use of walls with words of wisdom.
\end{abstract}

Key Word: Akidah Akhlak, Development, Islamic Character

\begin{abstract}
Abstrak
Tujuan dari penelitian ini untuk menganalisis pembentukan karakter Islami melalui pengembangan mata pelajaran akidah akhlak. Penelitian ini menggunakan metode deskriptif analitik dengan instrumen pengumpulan data melalui observasi, dokumentasi dan wawancara. Hasil penelitian menunjukan bahwa karakter islami adalah karakter yang bersumber dari ajaran Islam atau karakter yang bersifat islami. Pembentukan karakter islami di Madrasah Aliyah An-Najah Bekasi melalui pengembangan mata pelajaran akidah akhlak memiliki beberapa cara, di antaranya: kepala madrasah memerintahkan kepada guru yang mengampu mata pelajaran akidah akhlak untuk mencermati secara seksama tentang pendidikan karakter yang telah dicanangkan oleh pemerintah agar dapat dilaksanakan ke dalam pembelajaran sesuai dengan kondisi madrasah dan memperhatikan visi dan misi madrasah yang berkaitan dengan penerapan nilai-nilai karakter islami, guru pengampu mata pelajaran akidah akhlak diberikan kebebasan untuk mengembangkan karakter yang telah ada, sesuai dengan tingkatan jenjang masing-masing kelas dan menjalin komunikasi antara wali kelas dan guru bimbingan konseling untuk melihat sejauh mana implementasi penerapan karakter islami pada peserta didik serta pemanfaatan dinding dengan tulisan kata-kata bijak dan hikmah.
\end{abstract}


Kata Kunci: Akidah Akhlak, Karakter Islami, Pengembangan

\section{Pendahuluan}

Seiring

berkembang

pesatnya

kemajuan teknologi pada masa ini terdapat permasalahan yang dihadapi oleh dunia pendidikan secara khusus yaitu maraknya tindakan anarkis, dekadensi moral, pertengakaran antar peserta didik, tindakan bullying, menyontek di saat ujian tanpa rasa bersalah dan lain sebagainya.

Gambaran di atas tentunya menimbulkan banyak pertanyaan besar, sejauh mana peran pendididikan agama di madrasah dan bagaimana penyerapan materimateri keagamaan khususnya akidah akhlak terhadap peserta didik dengan adanya karakater perserta didik itu sendiri?

Hal ini merupakan pekerjaan besar khususnya bagi madrasah dalam memberikan penguatan-penguatan karakter islami kepada peserta didik melalui pengembangan pelajaran akidah akhlak. Sehingga beragam stragegi dan inovasi serta ide-ide yang muncul bisa membentuk peserta didik yang berkarakter.

Jika dicermati dari pegamatan beberapa kalangan bahwa pendidikan agama Islam belum memiliki kemampuan dalam menggarap proyek besar yang bermana perilaku dan moral bangsa. ${ }^{1}$ Sutrisno dalam

${ }^{1}$ Muhaimin, Nuansa Baru Pendidikan Islam: Mengurai Benang Kusut Dunia Pendidikan (Jakatara: PT. Raja Grafindo Persada, 2006), 35
Yuliharti mengutip perkataan K.H. Sahal Mahfudz, penekanan pada pencapaian yang sifatnya angka-angka dan nilai ujian (kuantitatif) adalah salah satu bentuk kegagalan pendidikan agama di sekolah sehingga mengabaikan internalisasi nilainilai akhlak dan karakter. ${ }^{2}$

Adapun definisi karakter adalah watak, sifat, tabiat. Berkarakter berarti mempunyai sifat. $^{3}$ Dalam pandangan Islam, karakter sangat identik dengan akhlak. Sedangkan dalam literasi bahasa Arab dapat kita jumpai akhlak bermakna watak, kelakuan, kebiasaan, perangai, dasar, tabiat, peradaban yang baik dan agama. ${ }^{4}$ Al-Jarjani mendefinisikan akhlak adalah ungkapan tentang perilaku bagi jiwa yang muncul darinya segala perbuatan dengan mudah tanpa membutuhkan waktu yang lama untuk berpikir. Jika yang muncul adalah perilaku dan perangai yang baik, maka hal tersebut dikategorikan akhlak yang baik dan sebaliknya apabila muncul darinya perilaku dan perangai yang tercela maka hal tersebut

\footnotetext{
2 Yuliharti, Pembentukan Karakter Islami Dalam Hadis Dan Implikasinya Pada Jalur Pendidikan Non Formal, POTENSIA: Jurnal Kependidikan Islam, Vol. 4, No. 2, Juli - Desember 2018, 216

${ }^{3}$ Peter Salim dan Yenny Salim, Kamus Bahasa Indonesia Kontemporer (Jakarta: Modern English Press, 2002), 102

${ }^{4}$ Jamil Shaliba, Al-Mu'jam al-Falsafi, Juz 1 (Mesir: Dar al-Kitab al-Misri, 1978), 112
} 
dikategorikan akhlak yang tercela dan Kurikulum pada Madrasah didalamnya buruk. $^{5}$ terdapat mata pelajaran akidah akhlak yang

Dalam pengertian sederhana karakter masuk dalam rumpun pendidikan agama islami dapat didefinisikan sebagai karakter Islam.

yang bersumber dari ajaran Islam atau

Ruang lingkup mata pelajaran akidah karakter yang bersifat islami, yang mana kata islami adalah sifat bagi akhlak itu sendiri. Oleh karenanya, karakter islami perbuatan yang dilakukan dengan mudah dan Qur'an al-Hadis. ${ }^{6}$ disandarkan kepada ajaran Islam.

Secara umum mata pelajaran yang

\section{Landasan Teori} ada di Madrasah Aliyah An-Najah Bekasi

Dalam penguatan dan pembentukan memiliki dua ranah, yaitu Pertama, mata pelajaran umum, seperti: bahasa Indonesia, matematika, sains, sosial dan lain sebagainya, Kedua, mata pelajaran agama yang mencakup fikih, sejarah kebudayaan Islam, akidah akhlak dan mata pelajaran lainnya. Berkaitan mata pelajaran akidah akhlak, mata pelajaran ini dimaksudkan agar peserta didik memeroleh materi dasar terkait dengan akhlak-akhlak islami yang diaplikasikan dalam kehidupan mereka serta terbentuknya karakter yang berdasarkan norma-norma islami.

Jika mengacu kepada UUD kurikulum madrasah telah diterbitkan keputusan Menteri Agama Nomor 183 Tahun 2019 tentang Kurikulum Pendidikan Agama Islam dan Bahasa Arab pada Madrasah Keputusan Menteri Agama Nomor 184 Tahun 2019 tentang Pedoman Implementasi nilai karakater terdapat beberapa kaidah yang perlu diperhatikan dan menjadi acuan. Anis Matta menyebutkan: Pertama, kaidah kebertahapan, bermakna proses perbaikan, perubahan, dan pengembangan., Kedua, kaidah kesinambungan, bermakna diperlukan keteguhan yang sifatnya terus menerus dalam melatih karakter. Ketiga, kaidah momentum, bermakna memanfaatkan segala situasi untuk pelatihan dan pendidikan. Keempat, kaidah motivasi intrinsik, bermakna keinginan anak yang muncul dengan tanpa unsur paksaan dari orang lain menjadi faktor pendorong terbentuknya karakter anak yang kuat dan sempurna. Kelima, kaidah pembimbing, bermakna pencapaian hasil yang baik membutuhkan 5 Al-Jarjani, At-Ta'rifat, (Mesir: Dar al-

${ }^{6}$ Thoyib Sah Saputra, Akidah Akhlak Untuk Fadhilah, 2000), 150 Jurnal Intelektual: Jurnal Pendidikan dan Studi Keislaman Volume 10, Nomor 2, Agustus 2020 
bantuan dan bimbinga orang lain ciptaan-Nya, kemandirian, tanggung jawab dibandingkan jika dilakukan seorang diri. $^{7}$ dan kedisiplinan, bijaksana dan kejujuran, Di antara jenis nilai karakter yang santun dan hormat, dermawan, suka dapat ditanamkan kepada peserta didik di kelas adalah sebagai berikut: Pertama, nilai menolong dan gotong royong, kreatif, pekerja keras dan percaya diri, karakter yang berhubungan dengan tuhan kepemimpinan dan keadilan, rendah hati dan misalnya; takwa dan religius. Kedua, nilai karakter yang berhubungan dengan diri baik, toleransi, kesatuan dan kedamaian. ${ }^{9}$ sendiri, misalnya: bertanggung jawab, kerja keras, disiplin, hidup sehat, jujur, berjiwa wirausaha, percaya diri dan lain lain. Ketiga, nilai karakter yang berhubungan dengan sesama manusia, misalnya; menghargai karya dan prestasi orang lain patuh pada aturanaturan sosial, sadar dengan hak dan kewajiban diri sendiri dan orang lain, santun dan lain lain. Keempat, nilai karakter yang berhubungan dengan kebangsaan misalnya; menghargai keberagaman Selanjutnya, menurut Character Count USA, ada sepuluh nilai karakter dasar manusia yang dapat dikembangkan antara lain: rasa hormat dan perhatian (respect and attention), peduli (care), berani (brave), jujur (honest), tanggung jawab (responsibility), ketulusan (sincerity), dapat dipercaya (trustworthy), kewarganegaraan (citizenship), integritas (integrity), dan tekun (diligent),. ${ }^{10}$

Menurut publikasi Pusat Kurikulum Badan Penelitian dan Pengembangan Kementerian Pendidikan Nasional berjudul nasionalis dan lain lain. Kelima, nilai Pedoman Pelaksanaan Pendidikan Karakter karakter yang berhubugan dengan telah mengidentifikasi 18 nilai pembentuk lingkungan misalnya; peduli sosial dan karakter yang merupakan hasil kajian lingkungan. ${ }^{8}$

empirik Pusat Kurikulum yang bersumber

Adapun mengenai pembahasan nilaidari agama, pancasila, budaya dan tujuan nilai karakter, Indonesia Heritage Foundation (IHF) telah menyimpulkan serangkaian nilainilai karakter menjadi sembilan pilar nilai karakter di antaranya: karakter cinta kepada Tuhan Yang Maha Esa dengan segenap

7 Muhammad Anis Matta, Membentuk $\underset{\sim}{\sim}$ Karakter Cara Islami (Jakarta: Al-I'tishom Cahaya

${ }^{9}$ Fika Pijaki Nufus, M. Dahlan R, M. Hilman Hakiem, Pola Pendidikan Karakter Melalui Penerapan 9 Pilar Di Sekolah Karakter Indonesia Heritage Foundation, Edutech Consultant Bandung Jurnal Aksara Public Volume 3 Nomor 2 Edisi Mei 2019 (56-71), h. 68.

10 Kholida Munasti, Rosmiati, Building The Care Environment Character Of Young Children In Playgroup Classes, Proceedings Of The International Conference On The Roles Of Parents In Shaping Children's Characters (Iceced), December 3-4, 2018, Anjong Mon Mata, Banda Aceh, Indonesia, h. 370. 
pendidikan nasional. ${ }^{11} 18$ Nilai-nilai karakter tersebut adalah jujur, kreatif disiplin, kerja keras, religius, mandiri, toleransi, rasa ingin tahu, demokratis, cinta tanah air, menghargai prestasi, semangat kebangsaan, bersahabat / peduli sosial, cinta damai, peduli lingkungan, komunikatif, gemar membaca, tanggung jawab.

Menurut Ari Ginanjar, berdasarkan dari nama-nama Allah ada tujuh karakter dasar yang dapat diteladani oleh manusia, antara lain: "Visioner, Tanggung Jawab, Jujur, Disiplin, Kerjasama Adil, Peduli, dan". 12

\section{Metode Penelitian}

Penelitian ini menggunakan pendekatan kualitatif karena peneliti bermaksud untuk memahami fenomena tentang apa yang dialami oleh subjek penelitian misalnya perilaku, persepsi, motivasi, tindakan dan lain sebagainya secara holistik dengan cara deskripsi dalam bentuk kata-kata dan bahasa pada suatu konteks khusus yang alamiah dengan memanfaatkan berbagai metode ilmiah. ${ }^{13}$

Metode yang digunakan dalam penelitian ini adalah metode deskriptif

11 Badan Penelitian dan Pengembangan Pusat Kurikulum dan Perbukuan. 2011. Panduan Pelaksana Pendidikan Karakter

${ }^{12}$ Eko Rubiyanto, Pendidikan Karakter Melalui Peningkatan Kualitas Lulusan SMA, Varia Pendidikan, Vol. 31, No. 1, Juni 2019: 73-80, h. 77.

${ }^{13}$ Moleong, Metodologi Penelitian Kualitatif, analitik yaitu suatu metode penelitian yang ditujukan untuk menggambarkan fenomenafenomena yang ada, yang berlangsung saat ini atau saat yang lampau dengan tidak mengadakan manipulasi atau pengubahan variabel-variabel bebas, namun menggambarkan kondisi apa adanya. ${ }^{14}$

Penulis mengumpulkan data penelitian ini dengan menggunakan teknik observasi, dokumentasi dan wawancara. Pada penelitian ini observasi dilakukan dengan cara mengamati pelaksanaan pembentukan karakter islami melaui pengembangan mata pelajaran akidah akhlak. Observasi dilakukan untuk memeroleh data terkait dengan pengembangan mata pelajaran akidah akhlak di Madrasah Aliyah An-Najah Bekasi. Sedangkan dokumentasi, peneliti mengambil dari dokumen-dokumen dan buku mata pelajaran akidah akhlak yang dijadikan bahan ajar sebagai sarana membentuk karakter islami.

Adapun terkait dengan wawancara, peneliti mewawancarai seluruh stakeholder yang berkaitan dengan pengembangan bahan ajar mata pelajaran akidah akhlak di Madrasah Aliyah An-Najah Bekasi. Wawancara dilakukan untuk memperoleh data terkait dengan pengembangan bahan ajar mata pelajaran akidah akhlak.

14 Muh. Fitrah dan Luthfiyah, Metodologi Penelitian; Penelitian Kualitatif, Tindakan Kelas \& Studi Kasus, (Sukabumi: CV Jejak, 2017), Cet. 1, h. (Bandung: Remaja Rosdakarya, 2017), Cet. 36, hal. $6 \quad 36$ Volume 10, Nomor 2, Agustus 2020 
Teknik analisis data yang digunakan adalah teknik analisis Miles and Huberman. Teknik analasis Miles and Huberman terdiri atas: reduksi data, penyajian data, dan kesimpulan serta verifikasi yang dilakukan secara interaktif dan berlangsung terus menerus sampai tuntas, sehingga datanya mencapai jenuh. ${ }^{15}$ Teknik analisis data ini digunakan untuk mendapatkan data yang valid terkait dengan penelitian pembentukan karakter islami melalui pengembangan mata pelajaran akidah akhlak di Madrasah Aliyah An-Najah Bekasi.

\section{Hasil Penelitian dan Pembahasan}

Sebelum membahas lebih jauh penelitian tentang pembentukan karakter islami melalui pengembangan mata pelajaran akidah akhlak di Madrasah Aliyah An-Najah Bekasi, peneliti memberikan gambaran sekilas tentang Madrasah Aliyah An-Najah Bekasi. Cikal bakal berdirinya Madrasah Aliyah An-Najah Bekasi berawal dari terbentuknya Yayasan

Hidayatunnajah (YWH). Yayasan Wakaf Hidayatunnajah (YWH) merupakan yayasan yang menaungi Madrasah Aliyah An-Najah Bekasi sebagai salah satu lembaga pendidikan Islam yang berada di wilayah kabupaten Bekasi.
Madrasah Aliyah An-Najah Bekasi berdiri di atas tanah wakaf Bapak Alm. H. Muhammad yang berlokasi di Jalan Raya Pebayuran, Desa Kertasari, Kecamatan Pebayuran, Kabupaten Bekasi Jawa Barat. Pada tanggal 20 Mei 1989 para pengurus Yayasan Wakaf Hidayatunnajah (YWH) mendirikan sebuah madrasah yang diberi nama Madrasah Aliyah An-Najah Bekasi. Seiring dengan berjalannya waktu, pihak pengurus Yayasan Wakaf Hidayatunnajah (YWH) bersama pengurus Madrasah Aliyah An-Najah Bekasi terus mengembangkan kualitas sumber daya manusia (SDM) dan sarana pendukung yang lainnya guna mewujudkan pendidikan yang unggul dalam Iman dan Takwa (imtak) dan Ilmu Pengetahuan dan Teknolog (iptek).

Hal tersebut merupakan salah satu upaya dari pihak Yayasan Wakaf Hidayatunnajah (YWH) bersama pengurus Madrasah Aliyah An-Najah Bekasi untuk mencetak generasi Rabbani yang memiliki karakter islami dan berwawasan luas dalam bidang sains dan teknologi. Pada saat ini tenaga pendidik dan tenaga kependidikan berjumlah 30 orang dengan rincian 25 tenaga pendidik dan 5 orang tenaga kependidikan. Adapun jumlah peserta didik mencapai 375 orang. Jumlah tersebut terbagi menjadi 15 rombongan belajar (rombel). Sedangkan luas tanah Madrasah Aliyah An-Najah Bekasi sekitar 1 hektar yang dibangun di atas tanah 
tersebut beberapa fasilitas, di antaranya setiap guru akidah akhlak menjalin kerjasama fasilitas pendidikan seperti kelas, kantor dengan wali kelas dan guru bimbingan guru, perpustakaan, laboraturium bahasa dan konseling untuk melihat sejauh mana laboraturium sains. Kemudian dibangun pula implementasi penerapan karakter islami pada di atas tanah wakaf tersebut fasilitas ibadah peserta didik, Kelima, pemanfatan dinding seperti masjid. Untuk mendukung kegiatan dengan tulisan kata-kata bijak dan hikmah. ${ }^{16}$ olahraga peserta didik, Madrasah Aliyah AnNajah Bekasi telah membangun fasilitas olahraga di antaranya lapangan futsal, lapangan basket dan lapangan volley.

Berdasarkan hasil observasi di lapangan, penguatan karakter di Madrasah Aliyah An-Najah Bekasi melalui pengembangan mata pelajaran akidah akhlak memiliki beberapa cara, di antaranya: Pertama, kepala madrasah memerintahkan kepada semua guru, utamanya guru pendidikan agama Islam yang mengampu mata pelajaran akidah akhlak untuk memperhatikan secara baik tentang pendidikan karakter yang telah digulirkan oleh pemerintah agar dapat diimplementasikan ke dalam pembelajaran yang disesuaikan dengan kondisi madrasah.

Kedua, kepala madrasah menghimbau setiap guru, utamamya guru pendidikan agama Islam agar memperhatikan visi dan misi madrasah yang berkaitan dengan penerapan nilai-nilai karakter islami. Ketiga, pihak guru akidah akhlak diberikan kebebasan untuk mengembangkan karakter yang telah ada sesuai dengan tingkatan jenjang masing-masing kelas. Keempat, Pada hakikatnya nilai katakter yang diterapkan pihak madrasah sangat banyak namun semua itu bermuara kepada enam butir pokok nilai karakter, yaitu: kejujuran, religius, ketangguhan, kepedulian, mandiri, dan bertanggung jawab.

Di antara metode yagn ditempuh oleh guru pendidikan agama Islam untuk mengintegrasikan nilai karakter pada silabus dan Rencana Pelaksanaan Pembelajaran (RPP) dengan cara mencuplik karakter yang ada pada silabus dari Kemenag kemudian dikembangkan oleh masing-masing guru.

\section{Pembahasan}

Pembentukan karakter islami di madrasah pada mata pelajaran akidah akhlak tidak bisa berdiri sendiri dan dipisahkan dari mata pelajaran lainnya yang ada di madrasah tersebut. Ibarat tubuh manusia akidah akhlak adalah ruh dari nilai pendidikan karakter yang tidak akan berfungsi tanpa bagian tubuh lainnya untuk mengimplementasikan nilai karakter yang telah ditentukan, mata pelajaran akidah akhlak harus terintegrasi

${ }^{16}$ Hasil wawancara dengan kepada Madrasah Aliyah Annajah Bekasi (Absyir Syaifurrahman alBakistani) pada 12 januari 2020 
dengan mata pelajaran lainnya untuk diampu oleh bagian piket yang bertugas pada mewujudkan dan mengimplementasikan nilai hari itu. ${ }^{18}$

karakter yang ada.

Mata pelajaran lain yang memiliki materi dan subtansi seirama dan sejalur serta berkaitan dengan mata pelajaran akidah akhlak adalah mata pelajaran adab islami. Mata pelajaran adab islami merupakan pengembangan dari mata pelajaran akidah akhlak yang membahasa secara spesifik tentang materi adab-adab islami dan penerapannya dalam kehidupan keseharian terhadap peserta didik.

Beberapa program yang ada di Madrasah Aliyah An-Najah Bekasi: Pertama, Apel Pagi, kegiatan ini adalah kegiatan rutin yang ada di madrasah setiap awal pekan sebelum peserta didik memulai aktifitas kegiatan belajar mengajar. Kegiatan ini dilakukan di halaman madrasah dan bertujuan agar setiap peserta didik membiasakan katakter disiplin terhadap waktu yang ditentukan. ${ }^{17}$

Kedua, Tadarus al-Quran, kegiatan ini dilakukan pada setiap awal pembelajaran dan diikuti oleh seluruh peserta didik dan dibimbing oleh guru mata pelajaran yang terjadwal pada jam pertama, jika guru tersebut tidak hadir, maka tadarus al-Quran
Ketiga, Salat Dhuhur secara berjamaah, kegiatan ini dilakukan di masjid madrasah yang cukup luas sehingga semua peserta didik dapat tertampung tanpa harus bergantian. Khusus hari jumat, peserta didik laki-laki melakukan salat jumat berjamaah dan didampingi oleh wali kelas dan guru Pendidikan Agama Islam. Adapun peseta didik perempuan melakukan kegiatan keputrian, seperti: (a) menjahit, (b) tataboga, (c) teori pola asuh dan anyaman. Salat dhuhur dilakukan setelah peserta didik lakilaki selesai melaksanakan kegiatan salat jumat.

Keempat, Jumat Bersih (jumsih), kegiatan ini merupakan kegiatan rutin pada setiap jumat sebelum masuk kelas. Setiap peserta didik diminta untuk mengambil sampah yang ada di lingkungan madrasah, taman, kelas dan lapangan. Kelima, Infak Jum'at, kegiatan ini dilakukan dengan tujuan untuk menumbuhkan sikap empati dan kedermawanan peserta didik. Kegiatan ini dipimpin oleh wali kelas dan ketua kelas masing-masing. Sedangkan hasil infak yang terkumpul diserahkan kepada pihak madrasah. Infak tersebut digunakan untuk bantuan kepada peserta didik jika ada yang

18 Hasil wawancara dengan Noor Agung Violetta Abdul Fattah, Lc Kepala Lembaga Tahfidz Quran (LTQ) di Madrasah Aliyah Annajah Bekasi) pada tanggal 13 Januari 2020 
sakit, keperluan masjid, seperti: pengadaan adalah kemandirian, kedisiplinan, tanggung buku iqra, al-Qur'an, sarung, mukena dan jawab, tolong menolong, saling menghormati lain sebagainya. Keenam, tahsin al-Quran, dan menghargai antar sesama dan kegiatan ini diikuti oleh seluruh peserta didik kepedulian.

pada setiap harinya setelah salat dhuhur.

Hal tersebut termasuk bagian dari Setiap pembimbing mengampu satu halaqah karakter islami. Kegiatan mukhayam tarbawi yang terdiri dari sepuluh peserta didik selama 20 menit untuk menyimak dan mengoreksi serta membenarkan bacaaan al-Quran peserta didik.

Ketujuh, bakti sosial, kegiatan dilaksanakan setiap tiga bulan sekali tepatnya setelah pelaksanaan Penilaian Tengah Semester (PTS). Dalam kegiatan ini pihak madrasah melibatkan peserta didik untuk menyalurkan bantuan berupa sembako dan kebutuhan sehari-hari kepada masyarakat sekitar yang tidak mampu. Tujuan diadakannya kegiatan ini sebagai bentuk kepedulian guna mempererat hubungan antara pihak madrasah dan masyarakat sekitar. $^{19}$

Kedelapan, Mukhayam Tarbawi. Menurut Ahmad Makmuri selaku Pembina kegiatan ekstrakurikuler menyatakan bahwa kegiatan ini merupakan nama lain dari kegiatan perkemahan. Istilah tarbawi pada kegiatan ini disandingkan dengan istilah mukhayam karena kegiatan perkemahan ini bertujuan untuk memberikan edukasi kepada peserta didik dalam banyak hal, di antaranya

\footnotetext{
${ }^{19}$ Hasil wawancara dengan Muhammad Ridho, S.Pd.I (Guru PAI di Madrasah Aliyah Annajah
} Bekasi) pada tanggal 13 Januari 2020 Jurnal Intelektual: Jurnal Pendidikan dan Studi Keislaman Volume 10, Nomor 2, Agustus 2020 adalah salah satu upaya pembinaan karakter islami terhadap peserta didik. ${ }^{20}$ Pengintregasian pendidikan karakter di Madrasah Aliyah An-Najah Bekasi didukung oleh fasilitas yang memadai berupa ruang kelas yang telah didesain sedemikian rupa sehingga proses belajar mengajar lebih kondusif dan nyaman bagi peserta didik.

Semua pihak baik kepala madrasah, guru dan tenaga kependidikan yang berada di madrasah menyadari bahwa pengintegrasian pendidikan nilai karakter membutuhkan keteladanan dari kepala madrasah, guru serta tenaga kependidikan terhadap internalisasi nilai karakter tersebut ke dalam kehidupan sehari-hari. Keteladanan mereka adalah cermin bagi peserta didik untuk melihat, merasakan, menganalisis yang kemudian mereka akan meng-copy\&paste setiap sikap yang diperankan oleh guru dalam kegiatan harian peserta didik.

Sikap dan gerak-gerik guru akan selalu dipantau oleh setiap peserta didik baik yang berkaitan dengan kedisiplinan, kejujuran, komunikatif, tanggung jawab dan

${ }^{20}$ Hasil wawancara dengan Ahmad Makmuri, S.Pd (Pembina Ekstarakurikuler di Madrasah Aliyah Annajah Bekasi) pada tanggal 15 Januari 2020 
lain sebagainya sehingga mereka akan segera direspon dalam kegiatan nyata peserta didik.

Dalam hal evaluasi, pihak madrasah dalam hal ini guru mata pelajaran akidah akhlak memberikan assessement terhadap internalisasi nilai kakakter pada diri peserta didik. Di antara cara yang dilakukan yaitu: Pertama, guru mata pelajaran akidah akhlak membuat lembar pengamatan etika dan moral. Pada lembar tersebut akan terlihat nilai setiap peserta didik dari setiap indikator yang telah ditentukan oleh pihak madrasah, dan setiap peserta didik akan mendapatkan nilai sesuai kriteria yang ada seperti: A (Amat Baik), B (Baik), C (Cukup), D (Kurang) dan E (Kurang Sekali), Kedua, pihak madrasah melibatkan teman sejawat dalam menilai nilai karakter pada peserta didiknya dengan menanyakan sikap mereka.

Berdasarkan hasil observasi pembentukan karakter islami terhadap peserta didik di Madrasah Aliyah An-Najah Bekasi terdapat beberapa faktor yang mendukung kegiatan tersebut, di antaranya: Pertama, sarana dan prasarana yang mendukung terbentuknya karakter islami, seperti masjid, perpustakaan dan kelas. Semua sarana tersebut dibuat untuk memfasilitasi terbentukanya karakter islami. Kedua, implementasi program pembiasaan 4S (Senyum, Sapa, Salam, Santun) dan program BINA (Bersih, Indah, Nyaman dan Aman). Program ini merupakan program yang pelaksanaannya dilakukan oleh seluruh elemen yang berada di dalam lingkungan Madrasah Aliyah An-Najah Bekasi, baik dari pihak guru dan tenaga kependidikan maupun peserta didik. Program ini merupakan salah satu di antara sekian program unggulan Madrasah Aliyah An-Najah Bekasi yang bertujuan untuk mendukung terbentuknya karakter islami terhadap peserta didik. Karena lingkungan menjadi faktor terbesar dalam membentuk karakter seseorang.

Ketiga, adanya program penghargaan kepada peserta didik yang berprestasi dan memiliki tauladan yang baik. Program ini sebagai bentuk apresiasi dari pihak Madrasah An-Najah Bekasi kepada peserta didik dan bentuk motivasi kepada mereka, agar menjadi pesera didik yang cerdas dan memiliki karakter islami. Penghargaan ini diberikan kepada peserta didik dalam bentuk medali dan hadiah uang tunai senilai satu juta rupiah yang digunakan untuk pembiayaan buku dan keperluan peserta didik di Madrasah.

Sehubungan dengan pembentukan karakter islami melalui pengembangan mata pelajaran akidah akhlak di Madrasah Aliyah An-Najah Bekasi, hal tersebut bukan berarti tidak ada kendala yang muncul. Di antara kendala-kendala muncul adalah Pertama, kurangnya pengawasan dalam mengevaluasi kurikulum yang berkaitan dengan pembentukan karakter islami. Proses 
pembentukan karakter islami yang sudah karakter islami yang terbentuk dalam diri berjalan sulit diukur seberapa besar peserta didik.

keberhasilannya tanpa ada evaluasi yang mendalam, sehingga terkadang tujuan yang ingin dicapai kurang maksimal dengan indikasi masih adanya perbuatan atau perkataan yang tidak sesuai dengan karakter islami yang dilakukan oleh peserta didik seperti berkata kasar atau tidak menghargai teman yang lain.

Kedua, sebagian orang tua peserta didik di rumah yang belum secara maksimal memberikan keteladanan yang sesuai dengan karakter islami terhadap peserta didik.

\section{Kesimpulan}

Dari pengamatan peneliti bahwa pihak madrasah sangat serius dan bersungguh-sungguh dapat mengimplemetasikan pembentukan karakter islami melalui pengembangan mata pelajaran akidah akhlak dan peserta didik dapat mengimplementasikan enam pokok karakter yang dirumuskan oleh pihak madrasah, yaitu: Pertama, kejujuran, Kedua, religius, Ketiga, Kerjasama antara pihak sekolah dengan orang tua diperlukan untuk pembentukan karakter islami peserta didik. Sekolah berusaha menanamkan karakter islami kepada peserta didik, sejatinya orang tua pun demikian, sehingga adanya sinergitas dalam mewujudkan tujuan yang sama yaitu pembentukan karakter islami terhadap peserta didik.

Ketiga, faktor lingkungan tempat tinggal peserta didik yang tidak mendukung dalam pembentukan karakter islami. Selain orang tua dan sekolah, lingkungan tempat tinggal atau lingkungan masyarakat juga memiliki peran dalam pembentukan karakter islami terhadap peserta didik. Lingkungan yang menerapkan dan menjaga norma-norma keislaman akan membawa pengaruh terhadap ketangguhan, Keempat, kepedulian, Kelima, mandiri, Keenam, bertanggung jawab. Di antara faktor pendukung dalam pembentukan karakter islami melalui pengembangan mata pelajaran akidah akhlak adalah adanya program lain yang mengarah kepada pembentukan karakter islami seperti apel pagi, tadarus al-Quran, salat dhuhur berjamaah, Jumat Bersih (jumsih), infak jumat, tahsin al-Quran, bakti sosial dan mukhayam tarbawi.

Di antara faktor pendukung pembentukan karakter islami melalui mata pelajaran Akidah dan Akhlak di Madrasah Aliyah An-Najah Bekasi adalah sarana dan prasarana yang memadai, implementasi program pembiasaan 4S (Senyum, Sapa, Salam, Santun) dan program BINA (Bersih, Indah, Nyaman dan Aman) serta adanya program penghargaan kepada peserta didik 
yang berprestasi dan memiliki tauladan yang baik. Adapun kendala-kendala yang muncul adalah kurangnya pengawasan dalam mengevaluasi kurikulum yang berkaitan dengan pembentukan karakter islami, sebagian orang tua peserta didik di rumah yang belum secara maksimal memberikan keteladanan yang sesuai dengan karakter islami terhadap peserta didik, faktor lingkungan tempat tinggal peserta didik yang tidak mendukung dalam pembentukan karakter islami.

\section{Daftar Pustaka}

Al-Jarjani. At-Ta'rifat. Mesir: Dar alFadhilah, 2000.

Badan Penelitian dan Pengembangan Pusat Kurikulum dan Perbukuan. Panduan Pelaksana Pendidikan Karakter. 2011.

Dharma Kesuma, dkk. Pendidikan Karakter Kajian Teori dan Praktek di Sekolah. Bandung: PT Remaja Rosdakarya, 2011.

Djam'an Satori, Aan Komariah. Metodologi Penelitian Kualitatif. Bandung: Alfabeta, 2017.

Fika Pijaki Nufus, M. Dahlan R, M. Hilman Hakiem."Pola Pendidikan Karakter Melalui Penerapan 9 Pilar Di Sekolah Karakter Indonesia Heritage Foundation". Edutech Consultant Bandung Jurnal Aksara Public Volume 3, Nomor 2, 2019.
Kholida Munasti, Rosmiati. "Building The Care Environment Character Of Young Children In Playgroup Classes". Proceedings Of The International Conference On The Roles Of Parents In Shaping Children's Characters (Iceced), Banda Aceh, 2018.

Matta, Muhammad Anis. Membentuk Karakter Cara Islami. Jakarta: AlI'tishom Cahaya Umat, 2003.

Moleong. Metodologi Penelitian Kualitatif. Bandung: Remaja Rosdakarya, 2017.

Muh. Fitrah dan Luthfiyah. Metodologi Penelitian; Penelitian Kualitatif, Tindakan Kelas \& Studi Kasus. Sukabumi: CV Jejak, 2017.

Muhaimin. Nuansa Baru Pendidikan Islam: Mengurai Benang Kusut Dunia Pendidikan. Jakatara: PT. Raja Grafindo Persada, 2006.

Rubiyanto, Eko. 'Pendidikan Karakter Melalui Peningkatan Kualitas Lulusan SMA", Varia Pendidikan, Volume. 31, Nomor. 1, 2019.

Salim Peter, Yenny Salim. Kamus Bahasa Indonesia Kontemporer. Jakarta: Modern English Press, 2002.

Saputra, Thoyib Sah. Akidah Akhlak Untuk Siswa. Semarang: PT. Karya Toha Putra, 1996.

Sutrisno. Pendidikan Islam Berbasis Problem Sosial. Yogyakarta: Ar-Ruzz Media, 2010 . 